\title{
Penicillium digitatum Suppresses Production of Hydrogen Peroxide in Host Tissue During Infection of Citrus Fruit
}

\author{
D. Macarisin, L. Cohen, A. Eick, G. Rafael, E. Belausov, M. Wisniewski, and S. Droby
}

First and sixth authors: U.S. Department of Agriculture-Agricultural Research Service (USDA-ARS), Appalachian Fruit Research Station, 2217 Wiltshire Road, Kearneysville, WV 25430; and second, third, fourth, fifth, and seventh authors: Department of Postharvest Science of Fresh Produce, Agricultural Research Organization, The Volcani Center, Bet Dagan 50250, Israel.

Accepted for publication 14 July 2007.

\begin{abstract}
Macarisin, D., Cohen, L., Eick, A., Rafael, G., Belausov, E., Wisniewski, M., and Droby, S. 2007. Penicillium digitatum suppresses production of hydrogen peroxide in host tissue during infection of citrus fruit. Phytopathology 97:1491-1500.

During the infection of citrus fruit by Penicillium digitatum there is little evidence of a host defense response. This suggests that $P$. digitatum has the ability to suppress host defenses. The current study demonstrates that $P$. digitatum suppresses a defense-related hydrogen peroxide $\left(\mathrm{H}_{2} \mathrm{O}_{2}\right)$ burst in host tissue. In contrast, the nonhost pathogen, Penicillium expansum, triggers production of a significant amount of $\mathrm{H}_{2} \mathrm{O}_{2}$ in citrus fruit exocarp. Using laser scanning confocal microscopy, we demonstrated that $P$. digitatum suppressed an elevation in $\mathrm{H}_{2} \mathrm{O}_{2}$ up to $42 \mathrm{~h}$ after inoculation. Nevertheless, $\mathrm{H}_{2} \mathrm{O}_{2}$ levels around wounds inoculated with

P. expansum increased by 63 -fold above the control. P. digitatum continued to suppress $\mathrm{H}_{2} \mathrm{O}_{2}$ production in citrus fruit exocarp up to $66 \mathrm{~h}$ postinoculation and $\mathrm{H}_{2} \mathrm{O}_{2}$ levels were actually threefold below that of noninoculated controls. In contrast, the $\mathrm{H}_{2} \mathrm{O}_{2}$ level was still about 11-fold above the control value in wound sites inoculated with $P$. expansum. Studies on the effect of organic acids (as $\mathrm{pH}$ modulators) on the response of citrus fruit to compatible and noncompatible pathogens indicated that pathogenicity was enhanced only when host-tissue acidification was accompanied by the suppression of $\mathrm{H}_{2} \mathrm{O}_{2}$. Additionally, pathogenicity of both $P$. digitatum and $P$. expansum on citrus fruit was significantly enhanced by the $\mathrm{H}_{2} \mathrm{O}_{2}$-scavenging enzyme catalase. Based on our study and previous reports regarding the potential involvement of citric acid and catalase in green mold pathogenesis, we suggest that these compounds are strongly associated with the virulence of $P$. digitatum.
\end{abstract}

Penicillium digitatum is the most devastating pathogen of citrus fruit, being responsible for about $90 \%$ of production losses during post-harvest handling. In spite of the application of fungicides and the increased implementation of new biological control strategies $(16,20)$, green mold continues to exhibit high infection pressure on stored citrus commodities worldwide. The inability to develop resistant germplasm and the lack of efficient and environment-friendly alternatives to control disease has increased the need for more detailed studies of host-pathogen interactions in order to characterize the virulence mechanism of $P$. digitatum.

Current knowledge of plant-fungal interactions indicates that a crucial role in host defense can be attributed to a rapid and massive generation of reactive oxygen species (ROS) within host cells, referred to us as an oxidative burst. In many cases, this initial response of a plant to a pathogen involves the production of hydrogen peroxide, $(31,32,49,55)$ which can function as a substrate for the oxidative cross-linking of cell wall proteins and is also involved in lignification $(8,39,48)$. It also functions as a signaling molecule to induce hypersensitive cell death and the expression of a wide array of defense-related genes in surrounding cells $(7,24,29,34)$. In addition, the toxicity of $\mathrm{H}_{2} \mathrm{O}_{2}$ may directly inhibit pathogen growth (35). A compatible pathogen must either tolerate the presence of ROS or suppress them, thereby preventing the ROS-dependent defense of a plant (11,51). In this regard,

Corresponding author: D. Macarisin

E-mail address: Dumitru.Macarisin@ars.usda.gov

* The $\boldsymbol{e}$-Xtra logo stands for "electronic extra" and indicates that Figures 1 and 2 appear in color online.

doi:10.1094/PHYTO-97-11-1491

This article is in the public domain and not copyrightable. It may be freely reprinted with customary crediting of the source. The American Phytopathological Society, 2007. catalase (EC 1.11.1.6), an antioxidant enzyme involved in detoxification of ROS (15), has been shown to be a virulence factor in several bacterial and fungal pathogens $(9,22,54,56,57,58)$. In addition, it is known that Penicillium chrysogenum secretes catalases into liquid media (12).

Evidence that $P$. digitatum suppresses fruit defenses was first provided by Ismail and Brown (28), who reported that elevation of phenylalanine ammonia-lyase (PAL) (EC 4.3.1.5) activity in citrus peel, induced by mechanical wounding, is inhibited around wounds inoculated with the fungus. Lisker et al. (33) later demonstrated that PAL activity is also suppressed in areas distant from inoculation sites. They also demonstrated that ethylene-induced PAL activity in intact or mechanically wounded fruits is inhibited by $P$. digitatum, further documenting the ability of this pathogen to disrupt the defense signaling pathway. More recently, Prusky et al. (42) suggested that $P$. digitatum compromises citrus fruit defense by acidifying host tissue, speculating that low ambient $\mathrm{pH}$ is optimal for expression and functioning of fungal polygalactouronases (PG). They demonstrated that during decay development, the pathogen produces citric and gluconic acids and actively uptakes ammonia ions and suggested that these two processes are associated with pathogenicity. However, these findings still do not explain why the entire defense machinery of the fruit (phytoalexins, pathogenesis-related (PR) proteins, lignification, etc.) is not triggered in response to invasion by $P$. digitatum or how the fungus disrupts defense signaling pathways in a host in regions distant from the site of inoculation.

We investigated whether or not $P$. digitatum suppresses the production of ROS by host cells during infection thereby interfering with signaling cascades responsible for triggering defense responses. We examined the production of ROS in citrus fruit after inoculation with a compatible $(P$. digitatum) and a nonhost pathogen ( $P$. expansum). Because the majority of studies on fun- 
gal-plant interactions have demonstrated the critical role of $\mathrm{H}_{2} \mathrm{O}_{2}$ in defense response $(6,7,27,32,37,50)$, we decided to focus on $\mathrm{H}_{2} \mathrm{O}_{2}$ as well. Also of importance was to explore the effect of organic acids and ROS-scavenging enzymes (as potential pathogenicity determinants) on the virulence of compatible and nonhost pathogens on a citrus fruit.

\section{MATERIALS AND METHODS}

Chemicals. 2',7'-Dichlorodihydrofluorescein diacetate $\left(\mathrm{H}_{2} \mathrm{DCF}\right.$ DA) (Molecular Probes Invitrogen, Eugene, OR) was dissolved in anhydrous dimethyl sulfoxide (DMSO) (Sigma-Aldrich, St. Louis, MO) to produce $10 \mathrm{mM}$ stock, which was frozen in aliquots. The 3,3'-diaminobenzidine tetrahydrochloride (DAB) (Sigma-Aldrich) was dissolved in water immediately prior to use. Catalase (CAT) (EC 1.11.1.6) was from Fluka Chemie, Buchs, Switzerland and superoxide dismutase (SOD) (EC 1.15.1.1) from Sigma-Aldrich. Unless stated otherwise, other chemicals were of analytical grade and were purchased from Sigma-Aldrich.

Plant material. Citrus fruits were obtained from a local orchard and used shortly after harvest or stored at an optimal storage temperature for each fruit (grapefruit and lemons at $11^{\circ} \mathrm{C}$, oranges at $6^{\circ} \mathrm{C}$ ) until use. Prior to inoculation, fruits were washed thoroughly with tap water and sterilized by drenching in a water solution of $0.05 \%$ hypochlorite for $2 \mathrm{~min}$. Fruits used for peel disk preparation were also surface sterilized by wiping with $70 \%$ ethanol.

Fungal cultures. Strains of $P$. digitatum and $P$. expansum were obtained from the pathogen collection of the Department of Postharvest Science, Volcani Center, Israel. Pathogens were cultivated on a potato dextrose agar (PDA) plate at $25^{\circ} \mathrm{C}$. Conidia suspensions were prepared by harvesting the spores from 2- to 3-weekold cultures using a bacteriological loop and suspending them in sterile distilled water. Spores were precipitated by centrifugation at 10,000 rpm for $5 \mathrm{~min}$ and resuspended in sterile distilled water to remove any remaining nutrients. Final spore concentrations were adjusted with a hemacytometer.

Inoculation and treatment of peel disks with organic acids and low pH buffer. Under aseptic conditions, peel disks were removed from the fruit with a 9-mm diameter cork borer. Albedo tissue was detached from flavedo with a sharp sterile blade. Flavedo disks were immersed in a water suspension of either $P$. digitatum or $P$. expansum conidia $\left(10^{4}\right.$ conidia/ml $)$, or in sterile water as a control, and then transferred into petri dishes lined with a moist sterile filter paper. Inoculated disks were incubated at $25^{\circ} \mathrm{C}$. At specific time intervals after inoculation, a lot of 16 disks of each variant was taken for analysis of $\mathrm{H}_{2} \mathrm{O}_{2}$ production as described below.

Organic acid or buffer treatments were performed by immersing peel disks for $10 \mathrm{~min}$ in sterile $20 \mathrm{mM}$ solution of citric $(\mathrm{pH}$ 2.1), oxalic ( $\mathrm{pH} \mathrm{1.8),} \mathrm{gluconic} \mathrm{(} \mathrm{pH}$ 6.2), ascorbic ( $\mathrm{pH} \mathrm{2.3)}$ acids or $\mathrm{KCl}-\mathrm{HCl}$ buffer ( $\mathrm{pH} 1.8$ ). Disks were then transferred into petri dishes lined with sterile filter paper moisturized with $5 \mathrm{ml}$ of corresponding acid or buffer and incubated as described above. Twelve hours after treatment, six disks of each variant were taken for analysis of $\mathrm{H}_{2} \mathrm{O}_{2}$ production as described below.

Fruit wounding, inoculation, and disease assessment. Fruit peels were wounded to a depth of $5.0 \mathrm{~mm}$ with a $1.25-\mathrm{mm}$ diameter needle. Four different sites around the blossom end on grapefruits and three different longitudinal sites on oranges and lemons were wounded. Thirty microliters of treatment solution or sterile water was pipetted into each wound prior to inoculation. For inoculation with a selected pathogen, a $20-\mu l$ drop of a $10^{5}$ conidia per milliliter suspension of either $P$. digitatum or $P$. expansum was pipetted into a wound. Inoculated fruits were incubated in darkness at $20^{\circ} \mathrm{C}$ in covered plastic trays lined with filter paper moisturized with sterile water $(150 \mathrm{ml} /$ tray $)$.

To assess the effect of ROS scavengers prior to inoculation with conidia, fruits were artificially wounded as previously described.
CAT and SOD were diluted in $50 \mathrm{mM}$ 2-( $N$-morpholino) ethanesulfonic acid (MES) buffer, $\mathrm{pH}$ 6.5, and pipetted into the wounds in a concentration range from 10 to 1,000 activity units (U) $/ \mathrm{ml}$.

To study the effect of organic acids, and low $\mathrm{pH}$ buffer on infection development, prior to inoculation with conidia, organic acids or buffer were pipetted into the artificial wounds in a concentration range from 10 to $200 \mathrm{mM}$ for $P$. digitatum and from 10 to $500 \mathrm{mM}$ for $P$. expansum. The percent of infected wounds, as well as lesion diameters, were determined 5 days after inoculation. At least 10 fruits were used for each treatment and each experiment was repeated three times. Results of a single representative experiment are presented. Data were analyzed statistically by Student's $t$ test at $P \leq 0.05$.

$\mathrm{H}_{2} \mathrm{O}_{2}$ detection by the DAB-uptake method. The DABuptake method, as described by Thordal-Christensen et al. (48), was used to study $\mathrm{H}_{2} \mathrm{O}_{2}$ production in lemon exocarp tissue in response to inoculation with $P$. digitatum and $P$. expansum. DAB is taken up by living plant tissue and polymerizes when it comes into contact with $\mathrm{H}_{2} \mathrm{O}_{2}$ resulting in a reddish brown polymer (27). Lemon fruit were wounded and inoculated with pathogens as previously described. As a positive control for uptake and reactivity of DAB, $100 \mu \mathrm{M} \mathrm{H}_{2} \mathrm{O}_{2}$ were injected into some wounds. Thirty-two hours after inoculation, $100 \mu \mathrm{l}$ of a solution containing $1 \mathrm{mg} / \mathrm{ml} \mathrm{DAB}$ were introduced into the wounds. Fruits were then incubated at room temperature for an additional $8 \mathrm{~h}$ period to allow DAB uptake and reaction with $\mathrm{H}_{2} \mathrm{O}_{2}$. Immediately before taking images, a thin exterior layer of flavedo above the inoculation site was cut off and $\mathrm{H}_{2} \mathrm{O}_{2}$ was visualized as a reddish brown coloration around the wound. Images were acquired with a Nikon (Nikon Instruments Corporation, Japan) color digital camera, model COOLPIX 990.

Confocal microscopic analyses of $\mathrm{H}_{2} \mathrm{O}_{2}$ production. $2^{\prime}, 7^{\prime}-$ Dichlorodihydrofluorescein enters cells in the diacetate form $\left(\mathrm{H}_{2} \mathrm{DCF}-\mathrm{DA}\right)$. Here, acetate groups are removed by intracellular esterases and charged dye $\mathrm{H}_{2} \mathrm{DCF}$ is retained by the cell as a nonfluorescent compound. Subsequent oxidation of $\mathrm{H}_{2} \mathrm{DCF}$ by $\mathrm{H}_{2} \mathrm{O}_{2}$ yields the highly fluorescent dichlorofluorescein (DCF). $\mathrm{H}_{2}$ DCF-DA loads readily into citrus flavedo cells and its optical properties make it amenable to laser scanning confocal microscopic analysis (2). Immediately before microscopic analysis, slices of flavedo were cut off around fruit wounds or from peel disks and immediately immersed in a small petri dish containing $10 \mathrm{ml}$ of $10.0 \mu \mathrm{M} \mathrm{H}_{2}$ DCF-DA in loading buffer (50 mM [MES] buffer, $\mathrm{pH}$ 6.5). $\mathrm{H}_{2}$ DCF-DA was freshly prepared from a $10 \mathrm{mM}$ stock solution in DMSO. Slices were maintained in the dark for $10 \mathrm{~min}$ to avoid light inducible dye oxidation. The slices were then removed, floated on a dish of fresh buffer to wash off excess dye, and affixed to a glass slide on which the slice remained immersed in $100 \mu \mathrm{l}$ of buffer. Sample examination and image acquisition were performed with an OLYMPUS IX 81 (Japan) inverted laser scanning confocal microscope (FLUOVIEW 500) equipped with a $488 \mathrm{~nm}$ argon-ion laser. The fluorescence probe was excited using a $488 \mathrm{~nm}$ laser beam and the emission was collected through a BA 515-525 filter. For autofluorescence, a BA 660 IF emission filter was used. Magnification can be increased by focusing the scanning laser beam on a smaller area of the object. The transmitted light images were obtained using Nomarski differential interference contrast (DIC) optics. The relative intensity of the fluorescence signal was estimated by calculating average pixel intensity from each consecutive $5 \mu \mathrm{m}$ focal plane of the flavedo slice using MICA software (Multi image analysis, CytoView, Israel). The final value of each measurement presented is the average and standard error (SE) from six different slices with the total number of focal planes ranging from 60 to 130 . Mean values were analyzed statistically by Student's $t$ test at $P \leq 0.05$.

Flourometry. Before sampling, flavedo disks were washed in a $50 \mathrm{mM}$ MES buffer, $\mathrm{pH}$ 6.5. $\mathrm{H}_{2}$ DCF-DA loading was performed 
following the same procedure as described for confocal microscopy, except that disk incubation with the dye was extended to $30 \mathrm{~min}$ to assure $\mathrm{H}_{2}$ DCF-DA penetration into all cells. After incubation, disks were thoroughly washed with MES and each sample was placed individually into the well of a Corning, 48well microtiter plate. During fluorescence measurement, disks were immersed in loading buffer without the dye. Intracellular $\mathrm{H}_{2} \mathrm{O}_{2}$ was determined by measuring fluorescence using a FL600microplate fluorescence reader (BioTek Instruments, Winooski, VT) equipped with a $485 \mathrm{~nm}$ excitation and a $530 \mathrm{~nm}$ reading filter. At least 16 flavedo disks were used for each time point sample measurement and for each variant.

\section{RESULTS}

Production of hydrogen peroxide in fruits after inoculation with $\boldsymbol{P}$. digitatum and $\boldsymbol{P}$. expansum. Thirty-two hours after inoculation, exocarp tissue around wounds inoculated with $P$. expansum and stained with $\mathrm{DAB}$, revealed a distinct brown reddish coloration, indicating a high concentration of $\mathrm{H}_{2} \mathrm{O}_{2}$ (Fig. 1). A similar intensity of DAB staining was also seen around wounds treated with a solution of $100 \mu \mathrm{M} \mathrm{H}_{2} \mathrm{O}_{2}$. In control wounds, inoculated only with water, DAB staining was less intense than in wounds treated with hydrogen peroxide or wounds inoculated with $P$. expansum. A faint, but obvious DAB polymerization was also observed at sites inoculated with $P$. digitatum. Based on qualitative differences in the intensity of DAB staining, it appeared that $P$. expansum induced a significant accumulation of $\mathrm{H}_{2} \mathrm{O}_{2}$ at inoculated sites, whereas $P$. digitatum inhibited production of $\mathrm{H}_{2} \mathrm{O}_{2}$ compared to wounds inoculated with either $P$. expansum or water.

The time course for production of hydrogen peroxide around inoculation sites was investigated using laser scanning confocal microscopy (Table 1). Eighteen hours after inoculation there was no significant differences in the level of $\mathrm{H}_{2} \mathrm{O}_{2}$ among treatments, as indicated by relative pixel intensity (RPI). By $42 \mathrm{~h}$ after inoculation, however, very high levels of $\mathrm{H}_{2} \mathrm{O}_{2}$ were observed in samples inoculated with $P$. expansum $(311.1 \pm 25.4 \mathrm{RPI})$ compared with samples inoculated with $P$. digitatum $(6.9 \pm 0.9 \mathrm{RPI})$ or samples treated with water $(4.9 \pm 0.2 \mathrm{RPI})$. By $66 \mathrm{~h}$ after inoculation, the level of $\mathrm{H}_{2} \mathrm{O}_{2}$ in sites inoculated with $P$. digitatum

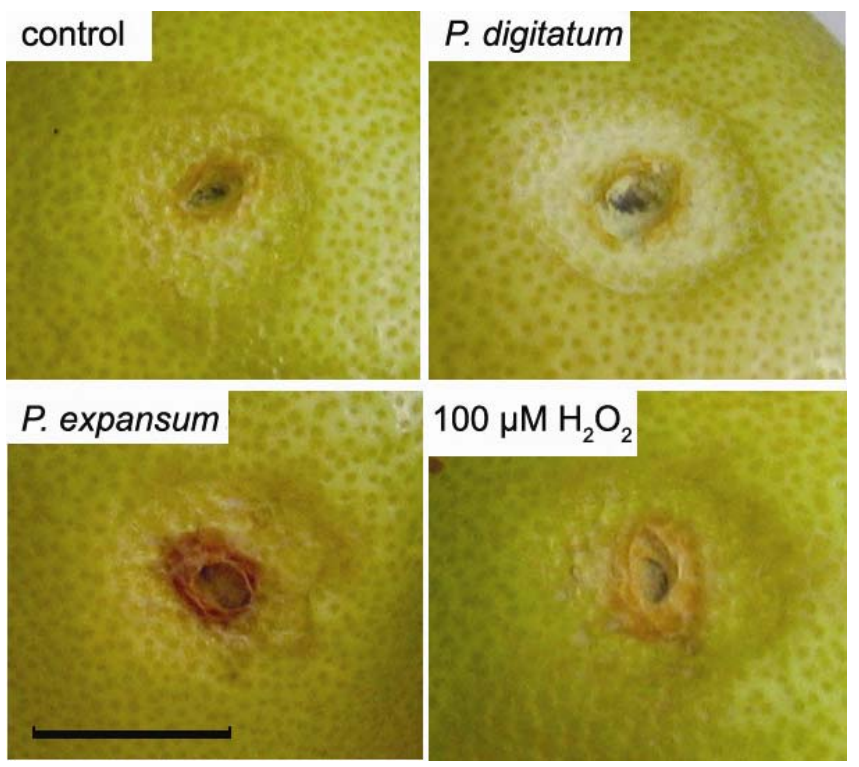

Fig. 1. Detection of $\mathrm{H}_{2} \mathrm{O}_{2}$ in lemon fruits by diaminobenzidine (DAB) staining. The appearance of brown DAB polymers indicates accumulation $\mathrm{H}_{2} \mathrm{O}_{2}$ in response to wounding (control), inoculation with Penicillium digitatum, P. expansum, or treatment with solution of $100 \mu \mathrm{M} \mathrm{H}_{2} \mathrm{O}_{2}$. Scale bar $=1 \mathrm{~cm}$. was approximately threefold below control samples. The concentration of $\mathrm{H}_{2} \mathrm{O}_{2}$ at $P$. expansum-infected sites was also significantly lower than in the previous measurement, however, it still exceeded the control level by nearly 12 -fold. Figure 2 illustrates a sample of the confocal fluorescence images, combined with the bright field images, of lemon fruits observed during this timecourse study. Figure 2A to $\mathrm{C}$ shows a gradual, low level of $\mathrm{H}_{2} \mathrm{O}_{2}$ accumulation in lemon peel in response to mechanical wounding. Figure 2D to $\mathrm{F}$ illustrates the suppression of $\mathrm{H}_{2} \mathrm{O}_{2}$ production in exocarp tissue of lemon inoculated with $P$. digitatum. Figure $2 \mathrm{G}$ to I illustrates the significant induction of $\mathrm{H}_{2} \mathrm{O}_{2}$ triggered by the nonhost pathogen, $P$. expansum. Between 18 and $42 \mathrm{~h}$ after inoculation, $P$. expansum induced a massive and widespread production of $\mathrm{H}_{2} \mathrm{O}_{2}$ by host cells in tissue surrounding inoculation sites. By $66 \mathrm{~h}$, the concentration of $\mathrm{H}_{2} \mathrm{O}_{2}$ in $P$. expansum samples decreased in the tissue underlying the inoculation site and was mainly present in cells surrounding oil glands and cells at the periphery of wounds.

Hydrogen peroxide production in inoculated peel disks. Production of hydrogen peroxide in inoculated flavedo disks was also investigated by monitoring DCF-fluorescence using a microplate reader (Fig. 3). Inoculated disks began to produce more $\mathrm{H}_{2} \mathrm{O}_{2}$ than controls as early as $8 \mathrm{~h}$ after inoculation. After reaching a maximum $\mathrm{H}_{2} \mathrm{O}_{2}$ level at $17 \mathrm{~h}$, (approximately $150 \%$ of the control value), the level of $\mathrm{H}_{2} \mathrm{O}_{2}$ in disks inoculated with $P$. digitatum dropped considerably below the control and was at a minimal detectable level at $36 \mathrm{~h}$. In contrast, the concentration of $\mathrm{H}_{2} \mathrm{O}_{2}$ in disks inoculated with $P$. expansum was threefold higher than the controls at 17 hours postinoculation (hpi) and began to decrease thereafter. However, even after 48 hpi, production of $\mathrm{H}_{2} \mathrm{O}_{2}$ in disks inoculated with $P$. expansum was about 1.75 -fold above the level in control samples.

Effect of organic acids and low $\mathrm{pH}$ buffer on hydrogen peroxide production in peel disks and infection development by $\boldsymbol{P}$. digitatum and $\boldsymbol{P}$. expansum on citrus fruit. To evaluate whether or not the accumulation of certain organic acids or a general acidification of tissue might result in inhibition of the oxidative burst, we monitored hydrogen peroxide production in flavedo tissue of lemon disks treated with $20 \mathrm{mM}$ solution of either citric $(\mathrm{pH} 2.1)$, oxalic $(\mathrm{pH} 1.8)$, gluconic $(\mathrm{pH}$ 6.2), or ascorbic ( $\mathrm{pH} 2.3$ ) acids, or $\mathrm{KCl}-\mathrm{HCl}(\mathrm{pH} 1.8)$ buffer. Significant differences in the level of hydrogen peroxide accumulation were found among treatments (Fig. 4). The histogram shows the level of $\mathrm{H}_{2} \mathrm{O}_{2}$ in treated tissue expressed as a percent of stimulation or inhibition relative to the control (set at 100\%). A strong inhibition of $\mathrm{H}_{2} \mathrm{O}_{2}$ production was detected in tissue treated with either oxalic or citric acid. Compared with controls, $\mathrm{H}_{2} \mathrm{O}_{2}$ production in these samples was suppressed by 98 and $96 \%$, respectively. A significant, but less strong suppression of $\mathrm{H}_{2} \mathrm{O}_{2}$ was detected in disks treated with ascorbic acid ( $81 \%$ less than in controls). In contrast, gluconic acid and $\mathrm{KCl}-\mathrm{HCl}$ buffer stimulated the synthesis of $\mathrm{H}_{2} \mathrm{O}_{2}$ by 35 and $231 \%$, respectively, compared with the control.

To assess the effect of organic acids and lowering of $\mathrm{pH}$ on the virulence of $P$. digitatum and $P$. expansum on citrus fruits, artificial wounds were pretreated with different concentrations of organic acids, or $\mathrm{KCl}-\mathrm{HCl}$ buffer, prior to inoculation with conidia

TABLE 1. Time-course production of $\mathrm{H}_{2} \mathrm{O}_{2}$ in lemon peel in response to inoculation with Penicillium digitatum and $P$. expansum

\begin{tabular}{lccr}
\hline & \multicolumn{3}{c}{ Time after inoculation (h) } \\
\cline { 2 - 4 } Treatment & 18 & \multicolumn{1}{c}{42} & \multicolumn{1}{c}{66} \\
\hline$P$. digitatum & $4.8 \pm 0.3$ & $6.9 \pm 0.9$ & $3.7 \pm 0.3$ \\
$P$. expansum & $3.3 \pm 0.2$ & $311.1 \pm 25.4$ & $112.7 \pm 8.6$ \\
Control & $4.6 \pm 0.3$ & $4.9 \pm 0.2$ & $9.8 \pm 0.6$ \\
\hline
\end{tabular}

a Concentration of $\mathrm{H}_{2} \mathrm{O}_{2}$ is expressed as relative pixel intensity. Values represent the mean \pm standard error, $n=60$ to 130 . 
of $P$. digitatum or $P$. expansum. Results indicated that treatment with citric, oxalic, and ascorbic acids effectively increased the virulence of both pathogens (Fig. 5). On grapefruits and oranges these compounds stimulated both the incidence and severity (as measured by lesion diameter) of green mold in a concentration dependent manner (Fig. 5A and B). Treatment of wounds with only $10 \mathrm{mM}$ citric or oxalic acids was sufficient to increase lesion diameter by 0.5 and $1.6 \mathrm{~cm}$, respectively, compared with controls in grapefruits, and by 1.3 and $0.2 \mathrm{~cm}$, respectively, in oranges. In contrast, gluconic acid and $\mathrm{KCl}-\mathrm{HCl}$ buffer did not stimulate green mold development. Instead $\mathrm{KCl}-\mathrm{HCl}$ significantly reduced infection incidence and severity at concentrations of $200 \mathrm{mM}$ on both grapefruit and oranges.

Pretreatment of wounds with citric, oxalic, or ascorbic acids (Fig. 5C and D) compromised host defenses to an extent that allowed the nonhost pathogen, $P$. expansum, to establish an infection. The stimulatory effect on infection incidence and severity was concentration dependent. Thus on white grapefruits, disease incidence was 25,58 , and $75 \%$ for 100,200 , and $500 \mathrm{mM}$ citric acid, respectively, 8 and $33 \%$ for 200 and $500 \mathrm{mM}$ ascorbic acid, respectively, and $100 \%$ in sites pretreated with $100 \mathrm{mM}$ and higher concentrations of oxalic acid (Fig. 5C). On oranges, $P$. ex- pansum succeeded to establish an infection in 46,41 , and $56 \%$ of inoculated sites pretreated with 100,200 , and $500 \mathrm{mM}$ citric acid, respectively, 31, 46, and $55 \%$ of sites pretreated with 100, 200, and $500 \mathrm{mM}$ ascorbic acid, respectively, and in $61 \%$ of sites pretreated with oxalic acid at concentrations $\geq 100 \mathrm{mM}$. At $10 \mathrm{mM}$, none of the compounds promoted infection of $P$. expansum on citrus fruit. The widest lesions developed around inoculation sites pretreated with the highest concentration of oxalic and citric acids.

Effect of ROS scavengers on compatible and nonhost interactions. The importance of ROS suppression for growth of $P$. digitatum and $P$. expansum on citrus fruit was examined by treatment of wounds prior to inoculation with CAT in order to reduce $\mathrm{H}_{2} \mathrm{O}_{2}$ and with SOD to remove $\mathrm{O}_{2}^{-}$. With $P$. digitatum (compatible interaction), pretreatment with CAT resulted in a significant increase in lesion diameter on all three citrus species compared with buffer controls (Fig. 6A to C). The largest lesion diameter was observed around wounds treated with $500 \mathrm{U} / \mathrm{ml}$ CAT. Application of $1,000 \mathrm{U} / \mathrm{ml}$ of SOD into wounds did not lead to an increase in lesion diameter or infection incidence in oranges and lemons inoculated with $P$. digitatum (Fig. 6A and C) and rather inhibited fungal development on white grapefruits, where both infection

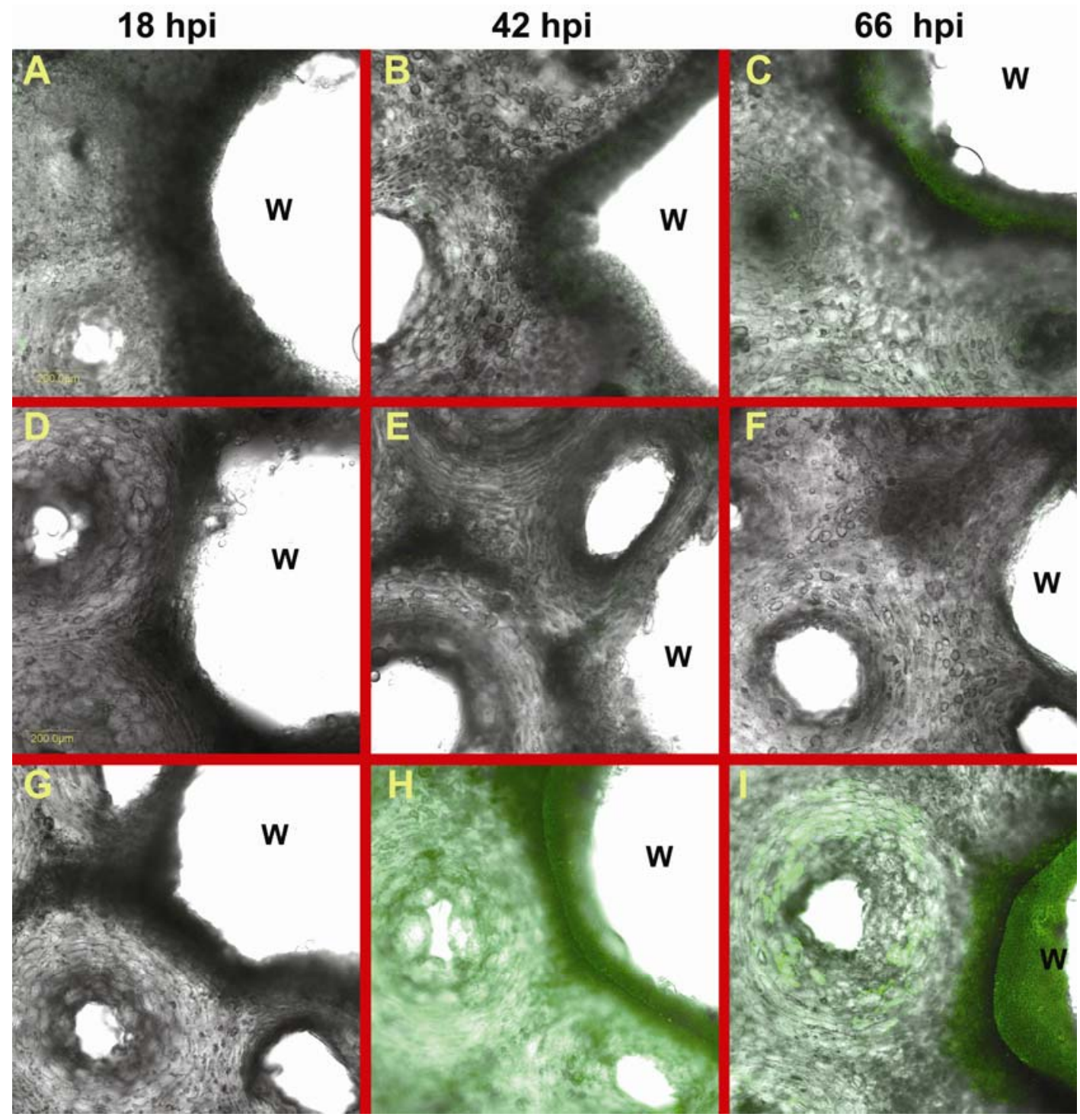

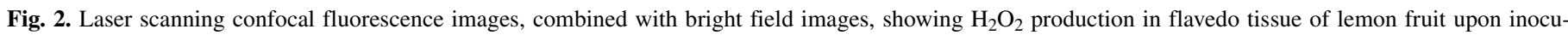

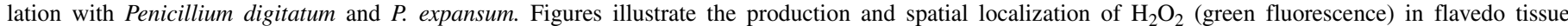

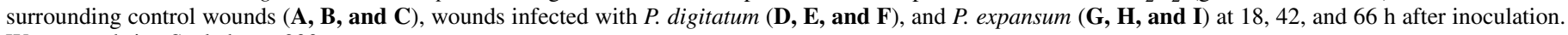
$\mathrm{W}=$ wound site. Scale bar $=200 \mu \mathrm{m}$. 
incidence and lesion diameter were reduced compared with the control (Fig. 6B).

With $P$. expansum (the nonhost interaction), wound pretreatment with CAT at concentrations $\geq 100 \mathrm{U} / \mathrm{ml}$ was shown to promote $P$. expansum infection on fruits of all three citrus species, (Fig. 6D to F). Although, P. expansum produced significantly smaller lesions compared with the compatible pathogen, infection incidence reached $100 \%$ at concentration of 500 and $1,000 \mathrm{U} / \mathrm{ml}$ of CAT. Inoculation of $P$. expansum into wounds pretreated with MES buffer alone (controls) or 1,000 U/ml of SOD, did not result in any infection.

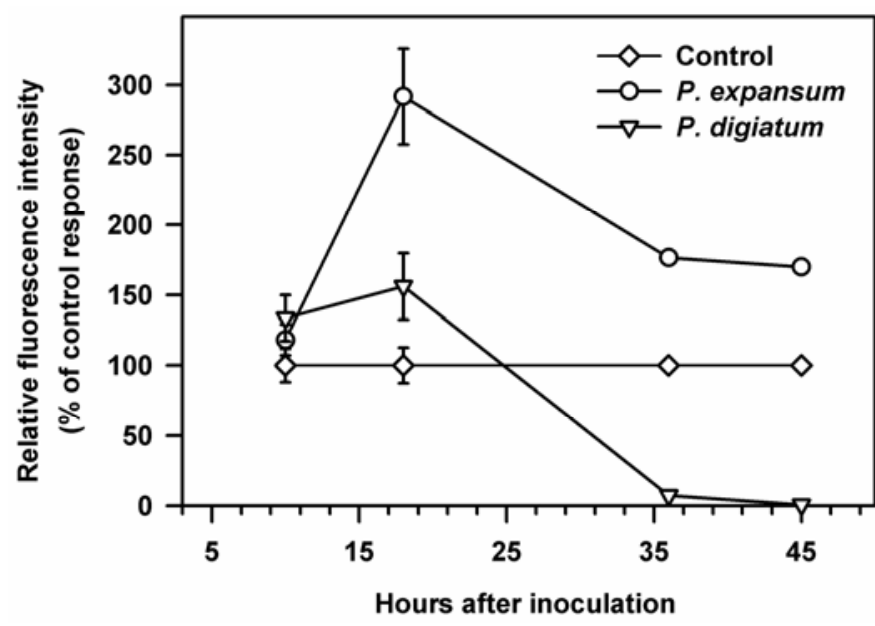

Fig. 3. Time-course production of $\mathrm{H}_{2} \mathrm{O}_{2}$, as measured by dichlorodihydrofluorescein-fluorescence, in peel disks of citrus fruit upon inoculation with Penicillium digitatum or $P$. expansum, compared with uninoculated controls. Values on the graph represent the mean \pm standard error, $n=16$.

\section{DISCUSSION}

Mechanisms of defense of citrus fruit against $P$. digitatum have been extensively studied $(1,21,26,36,40)$. As a result, information has been provided on the ability of various biotic and abiotic stimuli to enhance fruit defense by inducing the accumulation of phytoalexins and PR proteins $(13,16,17,41,47,53)$. There are also many reports on the composition of citrus peel volatiles and their antifungal properties $(18,44,46)$. The majority of studies indicate that flavedo tissue has the highest defense potential (3). In contrast, very little is known about Penicillium-fruit interaction from the pathogen's perspective. The process by which $P$. digitatum overcomes the arsenal of defense mechanisms cited above remains obscure, suggesting the need for more detailed investigations of pathogenicity determinants in P. digitatum.

The current study has demonstrated that during infection, $P$. digitatum suppresses the $\mathrm{H}_{2} \mathrm{O}_{2}$-oxidative burst in host cells, while the nonpathogen, $P$. expansum, triggers a massive accumulation of $\mathrm{H}_{2} \mathrm{O}_{2}$ in citrus fruit exocarp. A small but significant elevation in $\mathrm{H}_{2} \mathrm{O}_{2}$ was detected within 18 to $42 \mathrm{~h}$ after inoculation in host tissue around wounds inoculated with $P$. digitatum. Between 42 to $66 \mathrm{~h}$ after inoculation, $P$. digitatum suppressed hydrogen peroxide production and in fact, $\mathrm{H}_{2} \mathrm{O}_{2}$ levels were approximately threefold below that of noninoculated controls (Table 1 and Fig. 2F).

In contrast, $\mathrm{H}_{2} \mathrm{O}_{2}$ levels in fruit tissue inoculated with $P$. expansum became highly elevated (Fig. $2 \mathrm{H}$ ). The concentration of $\mathrm{H}_{2} \mathrm{O}_{2} 42 \mathrm{~h}$ after inoculation exceeded by 63 -fold the $\mathrm{H}_{2} \mathrm{O}_{2}$ level present in controls, (Table 1). At $66 \mathrm{~h}$, the concentration of $\mathrm{H}_{2} \mathrm{O}_{2}$ dropped in tissue surrounding the inoculation site but continued to be present in tissue close to the wound edges and in oil glands (Fig. 2I). In this tissue, the $\mathrm{H}_{2} \mathrm{O}_{2}$ level was still about 11-fold above the control value (Table 1). Approximately 4 to 5 days after inoculation with $P$. expansum, the first indications of an HR became visible as evidenced by a front of dead, lignified cells, on

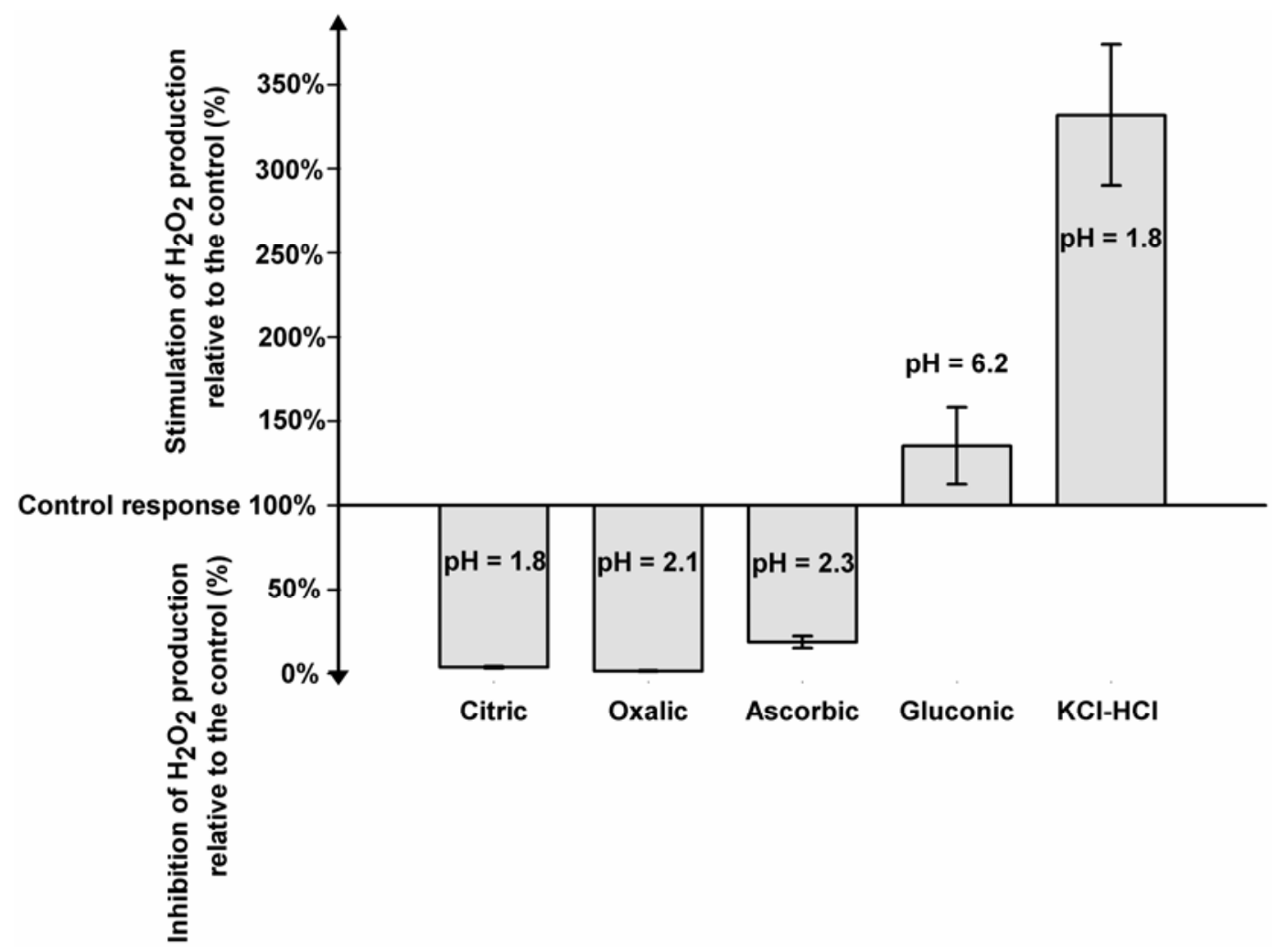

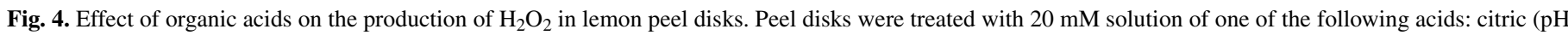
2.1), oxalic ( $\mathrm{pH}$ 1.8), gluconic ( $\mathrm{pH}$ 6.2), ascorbic $(\mathrm{pH} 2.3)$, or $\mathrm{KCl}-\mathrm{HCl}(\mathrm{pH} 1.8)$ buffer. Measurements of the average intensity of the fluorescence signal were taken $12 \mathrm{~h}$ after treatment using laser scanning confocal microscopy. $\mathrm{H}_{2} \mathrm{O}_{2}$ production is shown as percent stimulation or inhibition relative to the control which was set to $100 \%$. Mean \pm standard error, $n=60$ to 130 . 

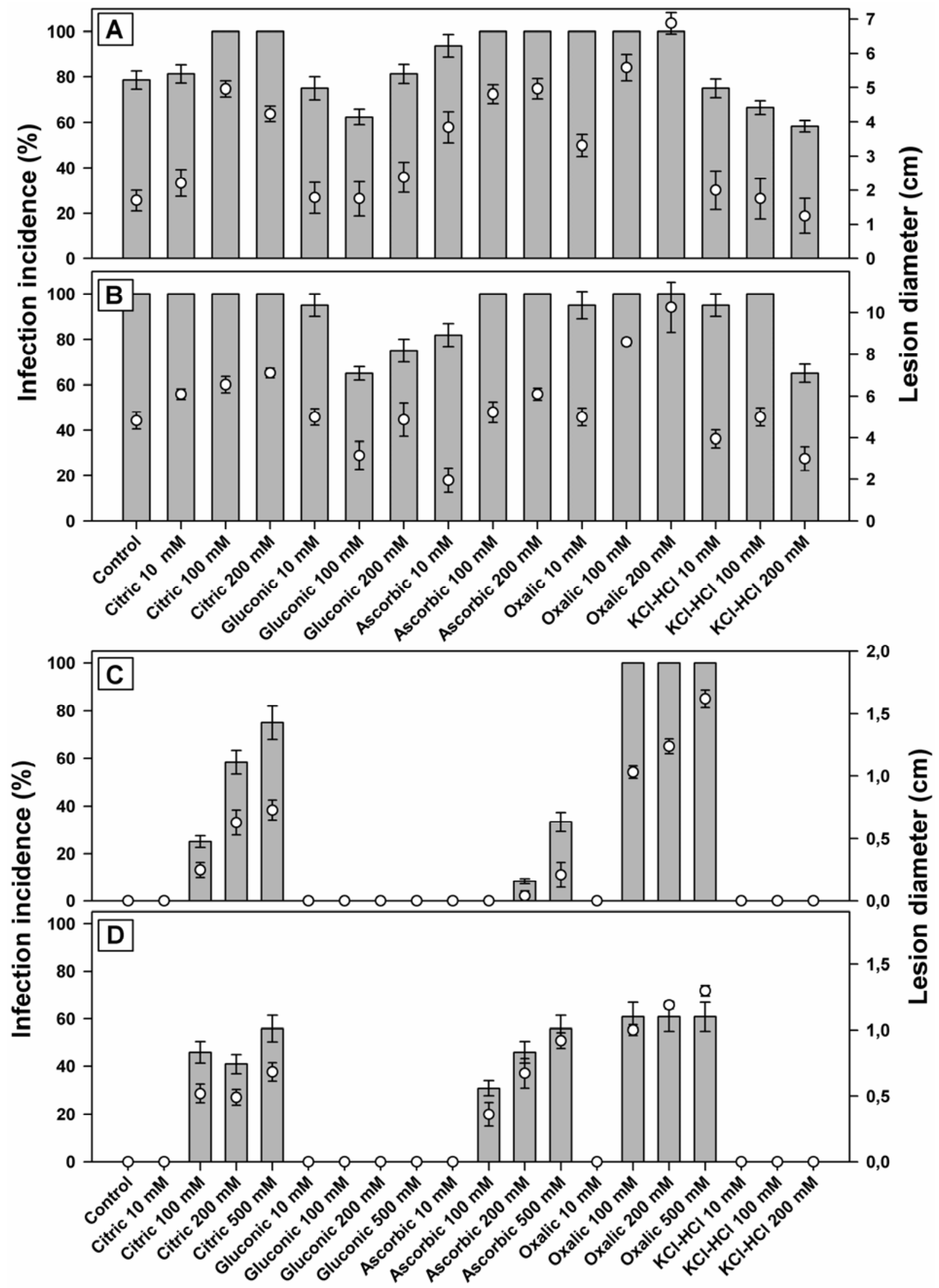

Fig. 5. Effect of organic acids on infection development by Penicillium digitatum and P. expansum on citrus fruits. A and B, Infection incidence and lesion diameter of $P$. digitatum on $\mathbf{A}$, white grapefruit and $\mathbf{B}$, oranges. $\mathbf{C}$ and $\mathbf{D}$, Infection incidence and severity of $P$. expansum on $\mathbf{C}$, white grapefruit and $\mathbf{D}$, oranges. Evaluation of disease incidence and lesion diameter was made 5 days after inoculation. Percent infection incidence is presented in columns and lesion diameter as open circles within each column. Mean \pm standard error, $n=20$. 
the edges of the wounds (data not shown). No lignified tissue was observed at $P$. digitatum inoculation sites (data not shown). A very similar succession of events, in regard to the spatial distribution of $\mathrm{H}_{2} \mathrm{O}_{2}$ and the $\mathrm{HR}$, has been described in the barley-powdery mildew interaction (52). Hydrogen peroxide accumulated first in mesophyll cells underlying the attacked epidermal cells. Subsequently, $\mathrm{H}_{2} \mathrm{O}_{2}$ disappeared from the mesophyll and accumulated in the cells bordering attacked epidermal cells.

Surprisingly, despite the fact that citrus peel is considered an inappropriate and even toxic environment for germination and growth of noncompatible pathogens (46), P. expansum germinated and temporarily grew in peel wounds of all three citrus species and triggered a defense-related oxidative burst in host tissue followed by an HR (data not shown). These data indicate that invasion of $P$. expansum into the fruit tissue was arrested by ROSdependent defenses, rather than by the antifungal effect of peel volatiles. Similarly, in avocado fruit, Beno-Moualem and Prusky (5) reported that the production of $\mathrm{H}_{2} \mathrm{O}_{2}$, triggered by Colletotrichum gloeosporioides, as well as the application of exogenous
$\mathrm{H}_{2} \mathrm{O}_{2}$ to avocado pericarp tissue, activated the phenyl-propanoid pathway, resulting in increased levels of antifungal compounds, which ultimately inhibited fungal development. Interestingly, Castoria et al. (10) have suggested that an essential characteristic of efficient yeast antagonists used to control postharvest diseases is their ability to tolerate ROS produced by host tissue. We have found that several yeast antagonists applied to citrus tissue can stimulate $\mathrm{H}_{2} \mathrm{O}_{2}$ (unpublished data). Given that $\mathrm{H}_{2} \mathrm{O}_{2}$ is a critical element in citrus fruit defense against postharvest pathogens, the ability of antagonist yeasts to stimulate and tolerate host ROS suggests the possible mode of action of biocontrol yeasts as local ROS elicitors and inducers of HR.

Because of difficulties in measuring ROS in intact plant material, time course studies that involve the direct detection of ROS have been conducted primarily on cell suspension cultures (14, 51). Unger et al. (51) followed the generation of superoxide in bean cell suspension cultures inoculated by aggressive and nonaggressive strains of Botrytis cinerea. They showed that both strains induced a similar early superoxide peak approximately
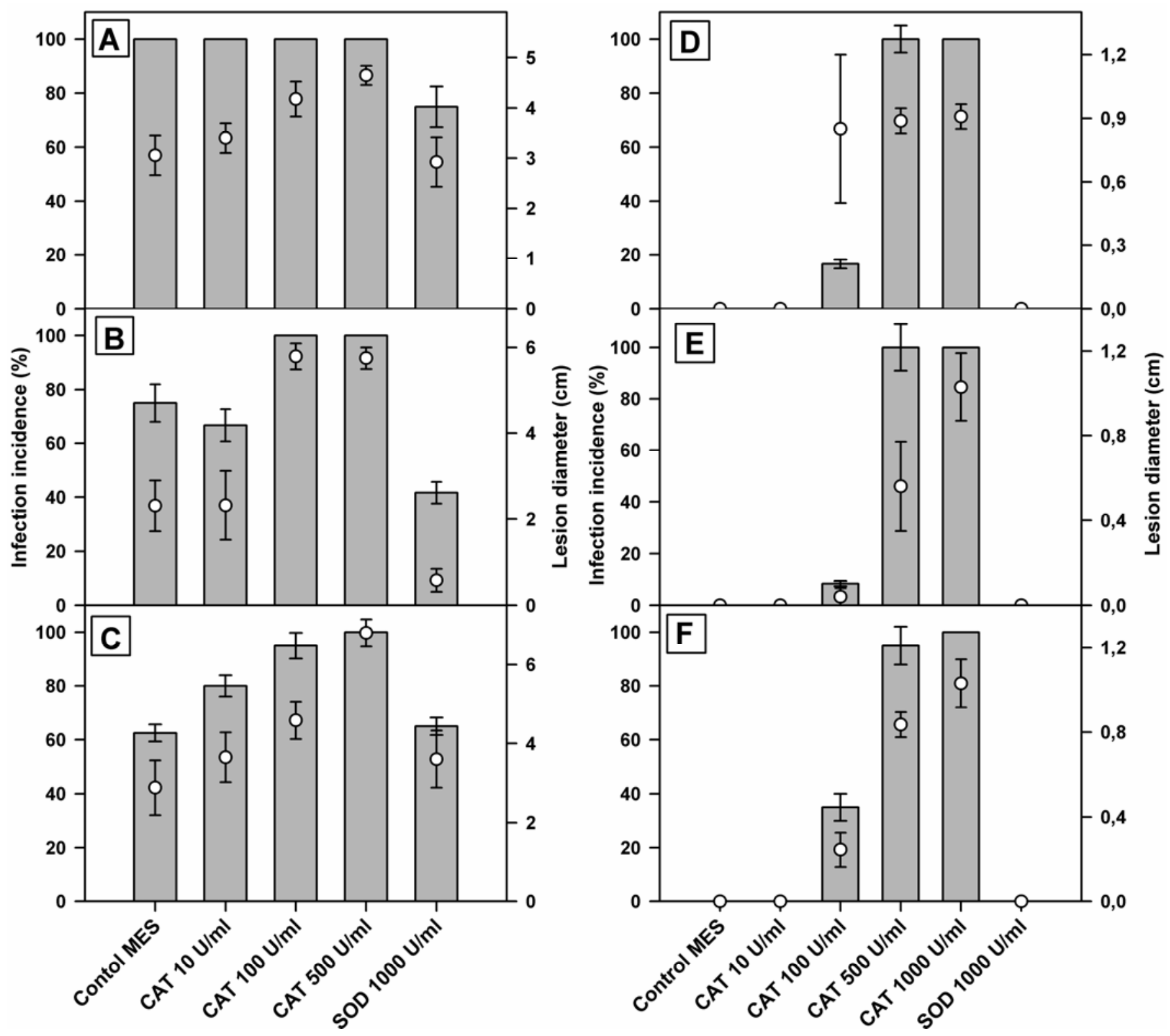

Fig. 6. The effect of reactive oxygen species scavengers, catalase and superoxide dismutase, on infection development by $\mathbf{A}$ to $\mathbf{C}$, Penicillium digitatum and $\mathbf{D}$ to $\mathbf{F}, P$. expansum on citrus fruit. Infection incidence and lesion diameter of $P$. digitatum on $\mathbf{A}$, lemon, $\mathbf{B}$, grapefruit, and $\mathbf{C}$, orange fruits. Infection incidence and lesion diameter of $P$. expansum on $\mathbf{D}$, lemon, $\mathbf{E}$, grapefruit, and $\mathbf{F}$, orange fruits. Measurements were made 5 days after inoculation. Percent infection incidence is presented in columns and lesion diameter as open circles within each column. Mean \pm standard error, $n=20$. 
18 hpi, however, the nonaggressive isolate induced an additional superoxide burst at $33 \mathrm{hpi}$, which was significantly stronger than the initial burst. The level of superoxide in suspension cells inoculated with the aggressive isolate was below the control level at 33 hpi. Despite the advantages of using a cell suspension culture/ pathogen system as a model for plant-fungus interactions, they cannot substitute for studies of intact biological systems with specific cell structural and functional organization. In the citrus fruit-Penicillium interaction, the earliest detected production of $\mathrm{H}_{2} \mathrm{O}_{2}$ in response to inoculation was between 18 and 42 hpi (Table 1).

Significant divergence between our findings and results obtained on cultured cells could be due to several factors. In a cell suspension, all host cells quickly and uniformly come in contact with either the pathogen or the pathogen's elicitor and respond simultaneously to the stimulus. Concomitant release of reactive intermediates by the triggered cells assures a higher concentration of the oxidant in the liquid medium, and is therefore easily detectable. In natural conditions, only a limited number of cells come into immediate contact with either the pathogen or its elicitor and a longer period of time may be required to transmit the signal to surrounding cells in order to generate a detectable oxidative response. In addition, the cell and tissue-type could inhibit the ability to respond to certain stimuli. Cultured cells are usually undifferentiated and therefore may be more responsive to external stimuli.

In an attempt to induce more uniform response by citrus cells, disk inoculation was employed. Immersing peel disks in a water suspension of fungal conidia can assure immediate contact with a large number of host cells and induce a greater reaction. With this approach an earlier (8 hpi) $\mathrm{H}_{2} \mathrm{O}_{2}$-defense response in host cells was detected (Fig. 3). However, the maximum intensity of the response was considerably lower than that observed in the in vivo experiment (Table 1). The lower intensity of the oxidative response detected in peel disks can be explained by their reduced defense potential compared to a whole fruit. Regarding the time course of $\mathrm{H}_{2} \mathrm{O}_{2}$ production in citrus tissue, our data are in good agreement with results reported by Tomankova et al. on tomato (49). They showed that in a susceptible tomato-powdery mildew pathogen (Lycopersicon esculentum-Oidium neolycopersici) interaction, the concentration of $\mathrm{H}_{2} \mathrm{O}_{2}$ became elevated from 12 to $28 \mathrm{~h}$ after inoculation and dropped thereafter, whereas in the resistant tomato-powdery mildew pathogen (L. hirsutum-O. neolycopersici) interaction, strong production of $\mathrm{H}_{2} \mathrm{O}_{2}$ was still evident at $48 \mathrm{hpi}$.

A comparative analysis of $\mathrm{H}_{2} \mathrm{O}_{2}$ accumulation in the compatible and nonhost citrus-Penicillium interaction indicates that for citrus fruit, a critical aspect of defense against postharvest pathogens is the ability to produce an oxidative burst within 25 to $50 \mathrm{~h}$ after inoculation followed by an HR that arrests the infection. On the other hand, the ability of $P$. digitatum to prevent this oxidative burst, by suppressing $\mathrm{H}_{2} \mathrm{O}_{2}$ production in the host cells during the first $25 \mathrm{~h}$ after inoculation, appears to be strongly associated with its pathogenicity.

Prusky et al. (42) ascribed $P$. digitatum virulence to its ability to secrete citric and gluconic acids which are believed to aid fungal invasion by developing a more suitable apoplastic $\mathrm{pH}$ for cell wall-degrading-enzymes secretion and activity $(42,43)$. We explored the ability of organic acids and other acidifying agents to suppress $\mathrm{H}_{2} \mathrm{O}_{2}$ production in host cells as well as the effect of these substances on the virulence of $P$. digitatum and $P$. expansum on citrus fruits. Our results indicated that $\mathrm{pH}$ reduction alone was insufficient to enhance pathogen virulence. Both in compatible and nonhost interactions, apoplast acidification only enhanced fungal pathogenicity when it was accompanied by the suppression of $\mathrm{H}_{2} \mathrm{O}_{2}$. Among the substances tested, only oxalic, citric, and ascorbic acids were able to both suppress $\mathrm{H}_{2} \mathrm{O}_{2}$ production in citrus peel tissue (Fig. 4) and enhance the virulence of both pathogens (Fig. 5). Gluconic acid and $\mathrm{KCl}-\mathrm{HCl}$ buffer stimulated $\mathrm{H}_{2} \mathrm{O}_{2}$ production in citrus fruit tissue (Fig. 4) and had an inhibitory effect on both infection incidence and disease severity (Fig. 5A and B). The antioxidant properties of ascorbic acid are well known as are its ability to act as an $\mathrm{H}_{2} \mathrm{O}_{2}$ scavenger. ThordalChristensen et al. (48) reported that application of exogenous ascorbic acid completely abolished $\mathrm{H}_{2} \mathrm{O}_{2}$ staining in cells undergoing HR in a barley-powdery mildew interaction. Our data are in agreement with previous reports on oxalic acid as a pathogenicity determinant in Sclerotinia sclerotiorum (19,23,59). Earlier proposed models to explain the role of oxalate in pathogenicity suggested (i) shifting of the apoplastic $\mathrm{pH}$ (4), (ii) chelation of cell wall $\mathrm{Ca}^{2+}(18)$, or (iii) direct toxicity of the oxalate to the host plant (38). However, more recently Cessna et al. (11) demonstrated that oxalic acid, secreted by Sclerotinia sclerotiorum, suppressed the defense-related production of $\mathrm{H}_{2} \mathrm{O}_{2}$ in bean and tobacco cultured cells. Although there are no reports on the production of either oxalic or ascorbic acids by $P$. digitatum, in our experiments, both acids enhanced the virulence of both pathogens, thereby providing additional indirect evidence in support of our hypothesis postulating a primary role for $\mathrm{H}_{2} \mathrm{O}_{2}$ in citrus fruit defense against postharvest pathogens.

$P$. digitatum is known to produce high amounts of citric acid during decay of a citrus fruit (42) and we showed that citric acid inhibits production of $\mathrm{H}_{2} \mathrm{O}_{2}$ in peel disks and enhances the pathogenicity of both $P$. digitatum and $P$. expansum. It remains unclear, however, how citric acid suppresses the production of $\mathrm{H}_{2} \mathrm{O}_{2}$. To suppress the oxidative burst, citrate would have to either inhibit the $\mathrm{H}_{2} \mathrm{O}_{2}$-generating oxidase directly or block a signaling step leading to the activation of the oxidase. Further investigations will be needed to explain the mechanism of suppression of the oxidative burst by citric acid. Additionally, given that citrus defense may be compromised by citric acid, citrate suppression of the oxidative burst could help explain the susceptibility of citrus fruit to other citrate-secreting fungi. For example, Aspergillus niger is pathogenic to citrus fruit and it is also known to be a large producer of citric acid (30). Interestingly, A. niger also infects citrus fruit without triggering a defense reaction and also produces disease symptoms very similar to those induced by $P$. digitatum (45).

If reactive oxygen species do have a role in citrus fruit defense, then antioxidant enzymes produced by $P$. digitatum may detoxify and even suppress the host oxidative burst. In support of this idea, Ballester et al. (3) performing spatial studies of antioxidant enzymes in citrus fruit infected by $P$. digitatum, have found a significant increase in CAT activity in portions of the flavedo completely colonized by the fungus. In our study, we showed that pretreatment of wounds with CAT, an $\mathrm{H}_{2} \mathrm{O}_{2}$ scavenger, significantly increased the pathogenicity of $P$. digitatum (Fig. 6A to C). Moreover, adding CAT into peel wounds prior to inoculation allowed $P$. expansum (nonhost pathogen) to develop infections on fruits of all three citrus species used in our investigation (Fig. 6D to $\mathrm{F}$ ). The $\mathrm{O}_{2}^{-}$scavenger, SOD, had a negligible effect on pathogenicity of $P$. digitatum and $P$. expansum in most cases (Fig. 6). However, application of SOD significantly reduced green mold incidence and severity on white grapefruits (Fig. 6B). This can perhaps be explained by the SOD-assisted conversion of $\mathrm{O}_{2}^{-}$to $\mathrm{H}_{2} \mathrm{O}_{2}$ which increased defense response and resulted in reduced susceptibility to $P$. digitatum. Although the generation of $\mathrm{O}_{2}{ }^{-}$has been reported to be an important defense response in certain plant/fungus interactions (51), our results indicate that production of $\mathrm{O}_{2}^{-}$is less critical to the defense of citrus fruit against fungal pathogens, while enzymatic removal of $\mathrm{H}_{2} \mathrm{O}_{2}$ by CAT compromises fruit defenses. In support of this statement, Mellersh et al. (37) showed that, $\mathrm{H}_{2} \mathrm{O}_{2}$ generation was the only oxidative response detected in three different plant-fungal combinations (powdery mildew and cowpea, anthracnose and tomato, rust fungus and pea). Furthermore, in all three combinations catalase- 
mediated removal of $\mathrm{H}_{2} \mathrm{O}_{2}$ resulted in increased pathogenicity (37). More recently, Zhang et al. (58) found constitutively high expression of catB transcripts in the pathogen Blumeria graminis, when it was incubated on barley leaves. Moreover, by employing an anti-CATB polyclonal antibody from Aspergillus fumigantus, they revealed an intensive circle of immunofluorescence at the host pathogen interface, at the appressorium germ tube tip, and within the halo area surrounding the host papilla, clearly demonstrating the implication of catalase in pathogenesis.

Collectively our results demonstrate that $\mathrm{H}_{2} \mathrm{O}_{2}$ is a critical element in citrus fruit defense. Whether it acts directly on the fungus or as a signaling molecule needs to be further established. However, the ability of $P$. expansum to germinate and temporarily grow in host tissue producing high levels of $\mathrm{H}_{2} \mathrm{O}_{2}$ indicates a more likely role for $\mathrm{H}_{2} \mathrm{O}_{2}$ in plant defense as a signaling molecule, rather than an antimicrobial. Evidence that $P$. expansum is able to tolerate some level of $\mathrm{H}_{2} \mathrm{O}_{2}$ is consistent with the recent work of Hadas et al. (25), which reported an accumulation of $\mathrm{H}_{2} \mathrm{O}_{2}$ in apple tissue infected with $P$. expansum. In contrast to our theory, attributing a primarily role for $\mathrm{H}_{2} \mathrm{O}_{2}$ in citrus host defense, Hadas et al. suggested that $\mathrm{H}_{2} \mathrm{O}_{2}$ detected in infected apple tissue is associated with pathogenicity of $P$. expansum. It should be noted, however, that they did not compare $\mathrm{H}_{2} \mathrm{O}_{2}$ production in infected tissue to that in wounded, uninoculated tissue. Therefore, the $\mathrm{H}_{2} \mathrm{O}_{2}$ detected in infected tissue could reflect solely the oxidative response of the host to wounding, or a small, temporary defenserelated increase in host $\mathrm{H}_{2} \mathrm{O}_{2}$ similar to the small increase we observed in the initial stages of the citrus fruit- $P$. digitatum interaction (Table 1 and Fig. 3). Despite the lack of comparable, quantitative data on $\mathrm{H}_{2} \mathrm{O}_{2}$ production, the results in Hadas et al. (25) and the present study, taken together suggest the possibility of contrasting pathogenicity factors in the $P$. digitatum-citrus and P. expansum-apple systems.

In early stages of infection development, $P$. digitatum successfully suppresses the defense-related oxidative burst in host tissue, thereby compromising fruit defense. Furthermore, we found that citric acid suppresses production of $\mathrm{H}_{2} \mathrm{O}_{2}$ in citrus exocarp and that the application of exogenous CAT into inoculation sites is sufficient to disrupt host defenses, making citrus fruit susceptible to the nonhost pathogen $P$. expansum. Based on the results of our current study, and reports documenting an increase in CAT in flavedo tissue colonized by $P$. digitatum (3), as well as the association of citric acid with $P$. digitatum pathogenicity (42), we suggest that these compounds play an important role in the pathogenicity of $P$. digitatum and appear to be responsible for suppressing the production of $\mathrm{H}_{2} \mathrm{O}_{2}$ in citrus fruit.

\section{LITERATURE CITED}

1. Afek, U., Orenstein, J., Carmeli, S., Rodov, V., and Bar Joseph, M. 1999. Umbelliferone, a phytoalexin associated with resistance of immature Marsh grapefruit to Penicillium digitatum. Phytochemistry 50:1129-1132.

2. Allan, A., and Fluhr, R. 1997. Two distinct sources of elicited reactive oxygen species in tobacco epidermal cells. Plant Cell 9:1559-1572.

3. Ballester, A., Lafuente, M., and González-Candelas, L. 2006. Spatial study of antioxidant enzymes, peroxidase and phenylalanine ammonialyase in the citrus fruit-Penicillium digitatum interaction. Postharvest Bio. Tech. 39:115-124.

4. Bateman, D., and Beer, S. 1965. Simultaneous production and synergistic action of oxalic acid and polygalacturonase during pathogenesis by Sclerotiorum rolfsii. Phytopathology 55:204-211.

5. Beno-Moualem, D., and Prusky, D. 2000. Early events during quiescent infection development by Colletotrichum gloeosporioides in unripe avocado fruits. Phytopathology 90:553-559.

6. Bindschedler, L., Dewdney, J., Blee, K., Stone, J., Asai, T., Plotnikov, J., Denoux, C., Hayes, T., Gerrish, C., Davies, D., Ausubel, F., and Bolwell, G. 2006. Peroxidase-dependent apoplastic oxidative burst in Arabidopsis required for pathogen resistance. Plant J. 47:851-863.

7. Borden, S., and Higgins, V. 2002. Hydrogen peroxide plays a critical role in the defense response of tomato to Cladosporium fulvum. Physiol. Mol. Plant Pathol. 61:227-236.
8. Brisson, L. F., Tenhaken, R., and Lamb, C. 1994. Function of oxidative crosslinking of cell wall structural proteins in plant disease resistance. Plant Cell 6:1703-1712.

9. Bussink, H., Oliver, R. 2001. Identification of two highly divergent catalase genes in the fungal tomato pathogen, Cladosporium fulvum. Eur. J. Biochem. 268:15-24.

10. Castoria, R., Caputo, L., De Curtis, F., and De Cicco, V. 2003. Resistance of postharvest biocontrol yeasts to oxidative stress: A possible new mechanism of action. Phytopathology 93:564-572.

11. Cessna, S., Sears, V., Dickman, M., and Low, P. 2000. Oxalic acid, a pathogenicity factor for Sclerotinia sclerotiorum, suppresses the oxidative burst of the host plant. Plant Cell 12:2191-2199.

12. Chaga, G. S., Medin, A. S., Chaga, S. G., and Porath, J. O. 1992. Isolation and characterization of catalase from Penicillium chrysogenum. J. Chromatogr. 604:177-183.

13. Chien, P., Sheu, F., and Lin, H. 2007. Coating citrus (Murcott tangor) fruit with low molecular weight chitosan increases postharvest quality and shelf life. Food Chem. 100:1160-1164.

14. Davies, D., Bindschedler, L., Strickland, T., and Bolwell, G. 2006. Production of reactive oxygen species in Arabidopsis thaliana cell suspension cultures in response to an elicitor from Fusarium oxysporum: Implications for basal resistance. J. Exp. Bot. 57:1817-1827.

15. De Gara, L., De Pinto, C., Tommasi, F. 2003. The antioxidant systems vis-à-vis reactive oxygen species during plant-pathogen interaction. Plant Physiol. Biochem. 41:863-870.

16. Droby, S., Cohen, L., Daus, A., Weiss, B., Horev, B., Chalutz, E., Katz, H., Keren-Tzur, M., and Shachnai, A. 1998. Commercial testing of aspire: A yeast preparation for the biological control of postharvest decay of citrus. Biol. Control 12:97-101.

17. Droby, S., Lischinski, S., Cohen, L., Weiss, B., Daus, A., Chand-Goyal, T., Eckert, J., and Manulis, S. 1999. Characterization of an epiphytic yeast population of grapefruit capable of suppression of green mold decay caused by Penicillium digitatum. Biol. Control 16:27-34.

18. Duccio, R., Caccioni, L., Guizzardi, M., Biondi, D., Renda, A., and Ruberto, G. 1998. Relationship between volatile components of citrus fruit essential oils and antimicrobial action on Penicillium digitatum and Penicillium italicum. Int. J. Food Microbiol. 43:73-79.

19. Dutton, M., and Evans, C. 1996. Oxalate production by fungi: Its role in pathogenicity and ecology in the soil environment. Can. J. Microbiol. 42:881-895.

20. El-Ghaouth, A., Smilanick, J., and Wilson, C. 2000. Enhancement of the performance of Candida saitoana by the addition of glycolchitosan for the control of postharvest decay of apple and citrus fruit. Postharvest Biol. Technol. 19:103-110.

21. Fajardo, J., McCollum, T., McDonald, R., and Mayer, R. 1998. Differential induction of proteins in orange flavedo by biologically based elicitors and challenged by Penicillium digitatum Sacc.1. Biol. Control 13:143-151.

22. Garre, V., Tenberge, B., and Eising, R. 1998. Secretion of a fungal extracellular catalase by Claviceps purpurea during infection of rye: Putative role in pathogenicity and suppression of host defense. Phytopathology 88:744-753.

23. Godoy, G., Steadman, R., Dickman, B., and Dam, R. 1990. Use of mutants to demonstrate the role of oxalic acid in pathogenicity of Sclerotinia sclerotiorum on Phaseolus vulgaris. Physiol. Mol. Plant Pathol. 37:179-191.

24. Grant, J., and Loake, G. 2000. Role of reactive oxygen intermediates and cognate redox signaling in disease resistance. Plant Physiol. 124:21-30.

25. Hadas, Y., Goldberg, I., Pines, O., and Prusky, D. 2007. Involvement of gluconic acid and glucose oxidase in the pathogenicity of Penicillium expansum in apples. Phytopathology 97:384-390.

26. Hasdai, M., Elmaci, C., Goldschmidt, E., Droby, S., and Porat, R. 2004. Isolation of a thioredoxin $\mathrm{h}$ cDNA from grapefruit peel tissue that is induced upon infection by Penicillium digitatum and elicitation of pathogen resistance. Physiol. Mol. Plant Pathol. 65:277-283.

27. Hückelhoven, R., Dechert, C., and Kogel, K. 2001. Non-host resistance of barley is associated with a hydrogen peroxide burst at sites of attempted penetration by wheat powdery mildew fungus. Mol. Plant Pathol. 2:199205.

28. Ismail, M. A., and Brown, G. E. 1979. Postharvest wound healing in citrus fruit: Induction of PAL in injured Valencia orange flavedo. J. Am. Soc. Hort. 104:126-129.

29. Lamb, C., and Dixon, R. 1997. The oxidative burst in plant disease resistance. Annu. Rev. Plant Physiol. Plant Mol. Biol. 48:251-275.

30. Leangon, S., Maddox, I., and Brooks, J. 2000. A proposed biochemical mechanism for citric acid accumulation by Aspergillus niger Yang No. 2 growing in solid state fermentation. World J. Microbiol. Biotech. 16:271275.

31. Levine, A., Tenhaken, R., Dixon, R., and Lamb, C. $1994 . \mathrm{H}_{2} \mathrm{O}_{2}$ from the oxidative burst orchestrates the plant hypersensitive disease resistance response. Cell 79:583-593. 
32. Li, A., Wang, M., Zhou, R., Kong, X., Huo, N., Wang, W., and Jia, J. 2005. Comparative analysis of early $\mathrm{H}_{2} \mathrm{O}_{2}$ accumulation in compatible and incompatible wheat-powdery mildew interactions. Plant Pathol. 54:308-316.

33. Lisker, N., Cohen, L., Chalutz, E., and Fuchs, Y. 1983. Fungal infections suppress ethylene induced phenylalanine ammonia-lyase activity in grapefruits. Physiol. Plant Pathol. 22:331-338.

34. Low, S., and Merida, R. 1996. The oxidative burst in plant defense: Function and signal transduction. Physiol. Plantarum 96:533-542.

35. Lu, H., and Higgins, J. 1999. The effect of hydrogen peroxide on the viability of tomato cells and of the fungal pathogen Cladosporium fulvum. Physiol. Mol. Plant Pathol. 54:131-143.

36. Marcos, J, Gonzalez-Candelas, L., and Zacarias, L. 2005. Involvement of ethylene biosynthesis and perception in the susceptibility of citrus fruits to Penicillium digitatum infection and accumulation of defense-related mRNAs. J. Exp. Bot. 56:2183-2193.

37. Mellersh, D., Foulds, I., Higgins, V., and Heath, M. 2002. $\mathrm{H}_{2} \mathrm{O}_{2}$ plays different roles in determining penetration in three diverse plant-fungal interactions. Plant J. 29:257-268.

38. Noyes, R. D., and Hancock, J. G. 1981. Role of oxalic acid in the Sclerotinia wilt of sunflower. Physiol. Plant Pathol. 18:123-132.

39. Olson, P., and Varner, J. 1993. Hydrogen peroxide and lignification. Plant J. 4:887-892.

40. Ortuño, A., Báidez, A., Gómez, P., Arcas, M., Porras, I., García-Lidón, A., and Del Río, J. 2006. Citrus paradisi and Citrus sinensis flavonoids: Their influence in the defense mechanism against Penicillium digitatum. Food Chem. 98:351-358.

41. Porat, R., Vinokur, V., Weiss, B., Cohen, L., Daus, A., Goldschmidt, E., and Droby, S. 2003. Induction of resistance to Penicillium digitatum in grapefruit by $\beta$-aminobutyric acid. Eur. J. Plant Pathol. 109:901-907.

42. Prusky, D., McEvoy, J., Saftner, R., Conway, S., Jones, R. 2004. The relationship between host acidification and virulence of Penicillium spp. on apple and citrus fruit. Phytopathology 94:44-51.

43. Prusky, D., and Yakoby, N. 2003. Pathogenic fungi: Leading or led by ambient pH? Mol. Plant Pathol. 4:509-516.

44. Scora, M., and Scora, R. 1998. Effect of volatiles on mycelium growth of Penicillium digitatum, P. italicum, and P. ulaiense. J. Basic Microbiol. 38:405-413.

45. Snowdon, A. 1990. Chapter 2. Citrus fruits. Page 59 in: A Color Atlas of Post-Harvest Diseases and Disorders of Fruits and Vegetables. Vol. 1. CRC Press, Boca Raton, FL.

46. Stange, R., Midland, S., Sims, J., and McCollum, T. 2002. Differential effects of citrus peel extracts on growth of Penicillium digitatum, $P$. italicum, and P. expansum. Physiol. Mol. Plant Pathol. 61:303-311.
47. Stevens, C., Khan, V., Lu, J., Wilson, C., Pusey, P., Igwegbe, E., Kabwe, K., Mafolo, Y., Liu, J., Chalutz, E., and Droby, S. 1997. Integration of ultraviolet (UV-C) light with yeast treatment for control of postharvest storage rots of fruits and vegetables. Biol. Control 10:98-103.

48. Thordal-Christensen, H., Zhang, Z., Wei, Y., and Collinge, D. 1997. Subcellular localization of $\mathrm{H}_{2} \mathrm{O}_{2}$ in plants. $\mathrm{H}_{2} \mathrm{O}_{2}$ accumulation in papillae and hypersensitive response during the barley-powdery mildew interaction. Plant J. 11:1187-1194.

49. Tomankova, K., Luhova, L., Petrivalsky, M., Pec, P., and Lebeda, A. 2006. Biochemical aspects of reactive oxygen species formation in the interaction between Lycopersicon spp. and Oidium neolycopersici. Physiol. Mol. Plant Pathol. 68:22-32.

50. Torres, R., Valentines, M., Usall, J., Vinas, I., and Larrigaudiere, C. 2003. Possible involvement of hydrogen peroxide in the development of resistance mechanisms in 'Golden Delicious' apple fruit. Postharvest Biol. Technol. 27:235-242.

51. Unger, Ch., Kleta, S., Jandl, G., and Tiedemann, A. 2005. Suppression of the defense-related oxidative burst in bean leaf tissue and bean suspension cells by the necrotrophic pathogen Botrytis cinerea. J. Phytopathol. 153:15-26.

52. Vanacker, H., Carver T., and Foyer, C. 2000. Early $\mathrm{H}_{2} \mathrm{O}_{2}$ accumulation in mesophyll cells leads to induction of glutathione during the hypersensitive response in the barley-powdery mildew interaction. Plant Physiol. 123:1289-1300.

53. Venditti, T., Molinu, M., Dore, A., Agabbio, M., and D'Hallewin, G. 2005. Sodium carbonate treatment induces scoparone accumulation, structural changes, and alkalinization in the albedo of wounded citrus fruits. J. Agric. Food Chem. 53:3510-3518.

54. Wilson, T., DeLisle, G., and Collins, D. 1995. Effect of inhA and katG on isoniazid resistance and virulence of Mycobacterium bovis. Mol. Microbiol. 15:1009-1015.

55. Wojtaszek, P. 1997. Oxidative burst: An early plant response to pathogen infection. Biochem. J. 322:681-692.

56. Wysong, D. R., Christin, L., Sugar, A. M., Robbins, P. W., and Diamond, R. D. 1998. Cloning and sequencing of a Candida albicans catalase gene and effects of disruption of this gene. Infect. Immune. 66:1953-1961.

57. Xu, X. Q., and Pan, S. Q. 2000. An Agrobacterium catalase is a virulence factor involved in tumorigenesis. Mol. Microbiol. 35:407-414.

58. Zhang, Z., Henderson, C., and Gurr, S. 2004. Blumeria graminis secretes an extracellular catalase during infection of barley: Potential role in suppression of host defense. Mol. Plant Pathol. 5:537-547.

59. Zhou, T., and Boland, J. 1999. Mycelial growth and production of oxalic acid by virulent and hypovirulent isolates of Sclerotinia sclerotiorum. Can. J. Plant Pathol. 21:93-99. 